INTERNATIONAL JOURNAL OF RESEARCHES IN BIOSCIENCES, AGRICULTURE AND TECHNOLOGY (C) VISHWASHANTI MULTIPURPOSE SOCIETY (Global Peace Multipurpose Society) R. No. MH-659/13(N) www.vmsindia.org

\title{
CHEMICAL QUALITY OF KHOA SOLD IN BHANDARA DISTRICT
}

\author{
B. S. Wanjari, S. G. Gubbawar, S. S. Asekar, S. S. Sardare and G.N. Jadhav \\ Animal Husbandry and Dairy Science Section, College of Agriculture, Nagpur (M.S.) India
}

\begin{abstract}
:
Total 60 samples of khoa (thick, semi-soft evaporated milk product) collected from four different sources of Bhandara district (viz. East, West, North, South region) with stratified randomization technique and analyzed them during three different fortnights for their chemical quality and possible adulteration in Animal Husbandry and dairy science Section, college of Agriculture, Nagpur during year 2014-2015. Chemical quality and adulteration was analyzed in laboratory by legal method prescribed in ISI Hand book. It was found that on an average 28.77, 29.78, 30.98, 28.65 per cent moisture, 24.70, 26.06, 23.84, 30.53 per cent fat, 16.24, 16.88, 18.77, 17.98 per cent protein, 4.25, 3.74, 4.09, 3.4 per cent ash, 71.20, 70.21, 69.01, 71.34 per cent total solids, $0.68,0.68,0.59,0.70$ per cent titrable acidity in east, west, north and south region khoa samples respectively. Adulteration of starch was more found in east, west and south region khoa. However, north region khoa gives negative test for starch for only one samples, hence north region khoa superior over other in respect to starch adulteration. So it clarified the ideas about superiority of north region khoa over the other region with clearly fulfilling the BIS specification with minimum percent of adulteration.
\end{abstract}

Keywords: Khoa, chemical quality, Sample

\section{Introduction:}

India has shown impressive growth in the milk production, achieving an annual production of 132.43 MT in the year 2012-2013, while in Maharashtra annual milk production is 8.73 MT. Uttar Pradesh being the top state in milk production with $23.330 \mathrm{MT}$. India is among the world's largest and fastest growing market for milk and milk products (Anonymous 20122013). In Indian dairy sector milk production during the year 2013-2014 is estimated at 140 million tonnes (MT) as per NDDB data. NDDB is running programme 'National Dairy Plan' to increase milk production for meeting the growing demand which is estimated to be around 200 MT by 2021-22. (Anonymous 201314). Milk and milk products constitute important nutritional components serve as the source of first class proteins especially for children and vegetarians. It supplies most essential elements like calcium and phosphorus along with numerous other essential major and minor substances (Karthikeyan, 2013).

Among the Indian indigenous dairy products, Khoa is a concentrated milk product. It is very rich in total solids and hence highly nutritious food in the diet of human beings. According to Indian Standard Institute, khoa shall not contain moisture less than 28 per cent and fat not less than 26 per cent on dry matter basis. Khoa is a major intermediate base product for a variety of sweets. (kurand, 2011). Nutritive value of khoa is very high. It contains fairly large quantities of muscle building proteins, bone forming minerals and energy giving fat \& lactose. It is also expected to retain fat soluble, vit.A and vit. $\mathrm{B}_{12}$ and also fairly large quantities of water soluble vit.B coned in the original milk. The manufacture and use of khoa has assumed great importance in our country. Food adulteration is fast growing worldwide as an industry. Global market of adulteration and fake goods is more than several hundred billion dollars which constitutes more than 10 percent of total trade. Indian market constitutes more than 30 percent of such trade, and rising very fast on day today basis. Hence a study on to finding out adulteration in market khoa in Bhandara district was taken up. In Bhandara district of Maharashtra, the preparation and marketing of khoa is the main occupation of the rural milk producers and almost entire khoa is disposed off in Bhandara district. So far no work has been taken up to assess the quality of khoa marketed in these mandies. Hence a study on the chemical quality and possible adulteration of market khoa in Bhandara district was taken up.

\section{Materials and Methods:}

The present investigation on evaluating chemical qualities and find out adulteration of khoa samples was carried out in the laboratory of Animal Husbandry and Dairy Science section, College of Agriculture, Nagpur during year 2014-15.

Collection of samples: Total 60 samples were collected from four sources (viz. east, west, north and south region) of Bhandara district by adopting stratified randomization technique with using vegetable parchment paper bag to avoid contamination and then mixed thoroughly each separate sample and analyzed them during three fortnights.

Compositional analysis of khoa samples: The collected market khoa samples were subjected 
to the chemical analysis for moisture, fat, protein, ash, total solids and titrable acidity by following different methods.

Determination of moisture: Moisture content of khoa samples was determined as per procedure prescribed in ISI Hand book of analysis sp: 18 (part XI): 1981.

Determination of fat: Fat content of khoa samples was determined by Gerber method. The fat percentage was directly read at the lower point of meniscus in Gerber's butyrometer as per BIS: SP 18, Part XI (1981).

Determination of protein: Protein content of khoa samples was determined by Kjeldahals method described by Aggarwal and Sharma (1961).

Determination of ash: Ash content of khoa samples was determined by as per procedure prescribed by IS - 1165 (1967).

Determination of total solids: Total solids content of khoa samples was determined by subtracting the moisture content in the samples as per procedure given by sp: 18 (part XI): 1981 . Determination of Titrable acidity: The acidity percentage of the khoa samples was determined as per the procedure recommended in ISI Handbook of food analysis, SP-18, (Part XI) Dairy products (1981).

Detection of Adulteration: Starch Detection:

Market khoa sample was tested for adulteration of starch. Starch was detected according to the method given in IS 1479 part I (1960).

Statistical analysis: Data generated in tabular form were statistically analyzed by using analysis of variance - two way classifications. Critical difference was calculated to study the significance.

\section{Result and Discussion:}

Khoa is heat desiccated product and important base material for different sweets. Due to higher nutrients and high water activity khoa is easily susceptible to growth of bacteria. The physico-chemical properties and microbial quality of khoa is initially good during production time and it will gradually deteriorate during storage and marketing hence analytical quality of khoa resulted and discussed below.

Results with regard to chemical quality of khoa sold in Bhandara district (Table 1) it revealed that, on an average moisture content of khoa samples was $28.77,29.78,30.98,28.65$ per cent in east, west, north and south region respectively. North region khoa recorded more percentages of moisture with fulfilling PFA specification. The present findings are accordance with Zariwala et al. (1974) reported was moisture per cent content of samples varied from 11.39 to 44.60 per cent with an average of 28.13 per cent in Bombay.

On an average fat content of east, west, north and south region khoa was 24.70, 26.06, 23.84 and 30.53 per cent respectively. According to BIS specifications, khoa should contain more than 25 per cent fat. So, south region khoa fulfilling its limitations. The present results are in agreement with Kakade et al. (2013) recorded average fat per cent of khoa $30.39,25.19,24.26$, and 22.65 from east, west, north, and south region in Nagpur city with collection of 60 samples. Average protein content significantly more in north region khoa (18.77 per cent) while in east, west and south region khoa was $16.24,16.88$ and 17.98 respectively. The data found to be close to the research work conducted by Kumar and Srinivasan (1982), Aneja (1997) and Kurand et al. (2013).

Table 1 indicates that the average percent of ash in khoa samples sold in Bhandara district was $4.25,3.74,4.09$ and 3.40 in east, west, north and south region khoa respectively. But according to PFA standard khoa should contain minimum 3.80 to 4.0 per cent ash so, north khoa indicate that specification. Total solids per cent content on an average in east, west, north and south region was $71.20,70.21,69.01$ and 71.34 respectively. Present findings are in line with Kumar and Srinivasan (1982) they find out on an average 71.62 and 69.07 per cent in market and cow's milk khoa samples respectively, Shintre (2005) recorded that on an average $72.80,69.89$ and 69.92 per cent total solids in Akola, Nandura and melghat respectively. Titrable Acidity average per cent recorded in east, west, north and south region khoa was $0.68,0.68,0.59$ and 0.70 respectively. Highest acidity indicate that the khoa product store for long period and then kept for selling in market. Hence north region khoa samples was superior for selling which content lowest acidity per cent. Present findings are close accordance with Ghatak and Bandyopadhya (1989) they observed that average 0.58 percent titrable acidity in total 57 khoa samples which collected from greater Calcutta market. Kurandet al. (2010) recorded that average per cent 0.597, 0.692, 0.690 in Washim, Karanja and Risod khoa samples in which total 90 samples collected from these three markets in Washim district.

From Table 2 it was revealed that adulteration was more found in south region khoa and least in north region khoa. Out of 60 
samples (i.e. 15 samples from each region) 8, 5, 1 and 11 samples given out positive test result in iodine test for starch detection from east, west, north and south region respectively. In sources khoa adulterated samples with starch recorded $53.33 \%, 33.33 \%, 6.66 \%, 73.33 \%$ in east, west, north, south, respectively.

Table 1. Average percent chemical composition of khoa sold in Bhandara district.

\begin{tabular}{|l|l|l|l|l|l|l|l|}
\hline \multirow{2}{*}{$\begin{array}{l}\text { Sr. } \\
\text { No. }\end{array}$} & Region & \multicolumn{7}{|c|}{ Chemical composition (\%) } \\
\cline { 3 - 8 } & & Moisture & Fat & Protein & Ash & Total Solids & Titrable Acidity \\
\hline 1 & East & 28.77 & 24.70 & 16.24 & 4.25 & 71.20 & 0.68 \\
\hline 2 & West & 29.78 & 26.06 & 16.88 & 3.74 & 70.21 & 0.68 \\
\hline 3 & North & 30.98 & 23.84 & 18.77 & 4.09 & 69.01 & 0.59 \\
\hline 4 & South & 28.65 & 30.53 & 17.98 & 3.40 & 71.34 & 0.70 \\
\hline & S.E. (m) \pm & 0.58 & 0.85 & 0.56 & 0.18 & 0.59 & 0.0064 \\
\hline & C. D. at 5\% & - & 2.95 & 1.75 & - & - & 0.022 \\
\hline
\end{tabular}

Table 2. Region wise result of Iodine test with per cent adulteration.

\begin{tabular}{|l|l|l|l|l|l|}
\hline \multirow{2}{*}{$\begin{array}{l}\text { Sr. } \\
\text { No. }\end{array}$} & Region & \multirow{2}{*}{$\begin{array}{l}\text { Total no of } \\
\text { samples }\end{array}$} & \multicolumn{2}{|l|}{ Iodine test result } & \multirow{2}{*}{$\begin{array}{l}\text { Per cent } \\
\text { adulteration }\end{array}$} \\
\cline { 4 - 5 } & & & Positive & Negative & \\
\hline 1 & East & 15 & 8 & 7 & $53.33 \%$ \\
\hline 2 & West & 15 & 5 & 10 & $33.33 \%$ \\
\hline 3 & North & 15 & 1 & 14 & $6.66 \%$ \\
\hline 4 & South & 15 & 11 & 4 & $73.33 \%$ \\
\hline
\end{tabular}

\section{Conclusion:}

During present study on chemical quality of khoa sold in Bhandara district, the chemical quality of khoa produced and marketed in north region of Bhandara district had better than east, west and south region khoa in Bhandara however, out of 60 samples from four region of Bhandara district, north region khoa was good in respect of finding adulteration with starch as compare to east, west and south region khoa.

\section{References:}

Aggrawal, A.C. and R.M. Sharma. 1961. Laboratory manual of milk inspection, $4^{\text {th }} \mathrm{Edn}$. Asian publication House Bombay.

Aneja, R.P. 1997. Traditional Dairy delicious. a compendium, Dairy Indian year book, 1997: 371-386.

Anonymous, 2012 - 2013. Annual Report 2012 2013, National Dairy Development Board,

Anonymous, 2012 - 2013. FAO and National Dairy Development Board website.www.fao.org/agriculture/dairy-gateway/milkproduction.

www.nddb.org/English/Statistics/pages/Milkproduction.aspx.

Anonymous, 2013 - 2014. The Hindu and The India Times news paper article. http://www.thehindu.com/. http://articles.economictimes.indiatimes.com/201406-26/news/_1_milk-production-national-dairy-plannddb.

Ghatak, P.K. and A.K. Bandopadhay. 1989. Chemical quality of khoa marketed greater in Calcutta. Indian J. Dairy science 42 (1): 123-124.

IS: 1165. 1967. Indian Standard specification for milk powder (whole and skim). Indian Standard Institution, ManakBhavan, New Delhi.

IS: 1479 (Part I).1960. Method of test for dairy industry. Rapid examination of milk. Indian Standard Institution, ManakBhavan, New Delhi.
IS: 1981. Handbook of food analysis in SP- 18 part XI. Bureau of Indian Standards, Manak Bhavan, Bahadurshah ZafarMarg, New Delhi:1.

Kakade, N. B., V. G. Atkare, S. R. Kute, N. N. Humane, P. N. Ingle. 2013. Physico chemical study of khoa sold in Nagpur city. J. Soils and Crops. 23 (1): $\underline{111-115}$

Karthikeyan, N. and C. Pandiyan, 2013.Microbial quality of Khoa and Khoa based milk sweets from different sources. International Food Research Journal. 20 (3): 1443-1447.

Kumar, G and M.R. Srinivasan. 1982. A comparative study on the chemical quality of three types of khoa. Indian J.Dairy Sci. 35 (1): 56-61.

Kurand, M. S., R. R. Shelke, S. G. Gubbawar and S. P. Nage, 2011. Quality of khoa sold in washim district. Food science research Journal. 2 (2): 200204.

PFA.(2005). Prevention of food Adulteration Act (1954) and Rules, 1955 (as amended).Universal Law Publishing Co. Pvt. Ltd. by AnsalDilkhush Industrial Estate, New Delhi.

Shintre, M. C. 2005. Chemical quality of khoa sold in Akola city. M.sc. thesis (unpub.) Dr. PDKV. Akola.

Zariwala, I.T., V.P. Sharma and K.S. Gaikwad. 1974. Market survey of chemical quality of khoa in Bombay. Indian J. Dairy Sci. 27 (1): 76-78. 